\title{
Approach to defining the object of energy efficiency assessment in industry
}

\author{
Natalia Verstina*, Natalia Solopova, Tatiana Meshcheryakova, Natalia Taskaeva and \\ Natalia Shchepkina \\ Moscow State University of Civil Engineering, Yaroslavskoe shosse, 26, Moscow, 129337, Russia \\ Funding: The reported study was funded by RFBR, project number 20-010-00754
}

\begin{abstract}
A scientific project focused on the development of a methodology for assessing energy efficiency classes of industrial facilities identified the primary research problems. The first and most important of them is the absence of a categorical and conceptual apparatus in the field of energy efficiency in industry, both in the Russian Federation and at the global level. This fact limits the definition of the system of indicators in the diagnosis of energy consumption. The study analyzed the definitions of an industrial facility contained in the current legislative and regulatory documents, as well as related assessment categories, such as: an industrial building and an industrial enterprise. The lack of unity in the definition of the identified categories, and in some cases their contradiction, demanded clarification of the category "industrial facility" as an object of diagnostics of energy consumption in industry, within the framework of an expert survey with the involvement of Russian and foreign experts in the field of energy. The practical significance of the results of the study is that the clarification of the category "industrial facility" is an integral attribute of the process of developing a methodological framework for assessing energy efficiency in industry, affecting its substantive part.
\end{abstract}

\section{Introduction}

Despite the significant scientific interest in realizing the potential of energy saving in the industrial sector of the economy, one of the key unresolved problems for many years has been the creation of tools and methods for effective management of energy consumption at industrial enterprises. This problem is associated with the lack of the possibility of applying a unified approach to the management of energy saving and energy efficiency in general for the industry, and the existing groundwork and applied mechanisms are of a discrete nature. The effectiveness of the implemented approaches has been confirmed only for individual enterprises, including those carrying out regulated activities and taking into account the possibilities of industry benchmarking based on a comparison of the world's best practices in the field of efficient energy management.

\footnotetext{
* Corresponding author: VerstinaNG@gic.mgsu.ru
} 
Since 2019, mandatory energy inspection has been abolished from Russian legislation. This change prevents the receipt of reliable information on the energy consumption of consumers, the formation of an informative database, suitable for accounting in the state information system in the field of energy saving and energy efficiency (GIS "Energy Efficiency") updated by the Ministry of Economic Development of the Russian Federation. It also interferes with the reliable determination of the potential for the implementation of energy-saving measures and the timely monitoring of the degree of achievement of the target indicators of the comprehensive plan of measures to improve the energy efficiency of the national economy. To identify barriers to energy conservation and energy efficiency of industrial enterprises that affect the dynamics of the energy intensity of GDP and the implementation of government priorities in this area, it is necessary to assess the energy efficiency of industrial facilities that are key consumers of energy resources. The primary task in solving this issue is the formation of a categorical and conceptual apparatus in the field of energy efficiency in industry.

The above aspects determined the purpose of this study - to identify the object of diagnostics of energy consumption in the industry, proposed as an "industrial facility", as a category planned for inclusion in the categorical-conceptual apparatus of a scientific project to develop a methodology for assessing energy efficiency classes of industrial facilities.

Achievement of this goal led to the formulation and consistent solution of the following tasks: - systematization of the Russian regulatory framework according to sources relevant for assessing the energy efficiency of industrial facilities;

- analysis of international standards, foreign regulatory and methodological framework in the field of energy efficiency;

- comparison of related categories that are possible to determine the object of accumulation of energy costs;

- determination of the category "industrial facility" for the purpose of diagnosing the energy consumption of industrial enterprises and assessing the efficiency of energy resources use.

Among domestic scientists who have made a significant contribution to the development of energy conservation and energy efficiency, it is worth noting: I. A. Bashmakov, who considers the problems of assessing the energy intensity of the Russian economy, improving the efficiency of energy supply in various regions, etc. [1-2]; experts on assessing the energy efficiency of buildings Yu. A. Tabunshchikova, N. V. Shilkina and M. M. Brodacha, who pay attention to various aspects of energy conservation, are the developers of a scientific methodology for assessing investments in energy saving measures [3-6]. Their work had a great influence on the definition of modern approaches to assessing the compliance of real estate with general principles of sustainable development.

Among the foreign scientists involved in the assessment of energy efficiency, it is worth noting: Mokhtara, M. Nasootib [7], D. Borozan, D. P. Starcevic [8], B. Ezicia, G. Eğilmezb, R. Gedikc [9], O. T. Adenuga, K. Mpofu, B. I. [10], Y Hanab, R. Zhouab, Z. Gengab, J. Baiab, B. Mac, J. Fand [11], J. Palma, P. Thollanderbc, [12], A. Gonzalez Hernandeza, S. Cooper-Searleb, Alexandra C.H. Skeltona, Jonathan M. Cullena [13].

\section{Materials and Methods}

During the study, the following methods were used:

- Method of analysis and synthesis. The concepts were formed as a result of the transition from the analysis and synthesis of various aspects of the energy efficiency of industrial facilities to the selection and consolidation of their general properties through abstraction and generalization. As a result, a logically built system of special terms was formed and logical elements in the research methodology were highlighted. 
- The method of expert assessments. The use of this method made it possible to clarify the conceptual and categorical apparatus of the study used in the development of the Methodology for assessing energy efficiency classes of industrial facilities. When conducting an expert survey to collect primary information, the methods of questioning and interviewing were used. The use of the method of expert assessments within the framework of this study made it possible to obtain, based on the opinions of foreign and Russian experts in the field of energy conservation and energy efficiency, new information that is absent in foreign and Russian literature and regulatory sources, which is necessary for the development of a Methodology for assessing energy efficiency classes of industrial facilities.

To conduct the study, a conceptual model was developed that reflects the stages in the formation of a categorical-conceptual apparatus in the field of energy efficiency in industry (Fig. 1). 


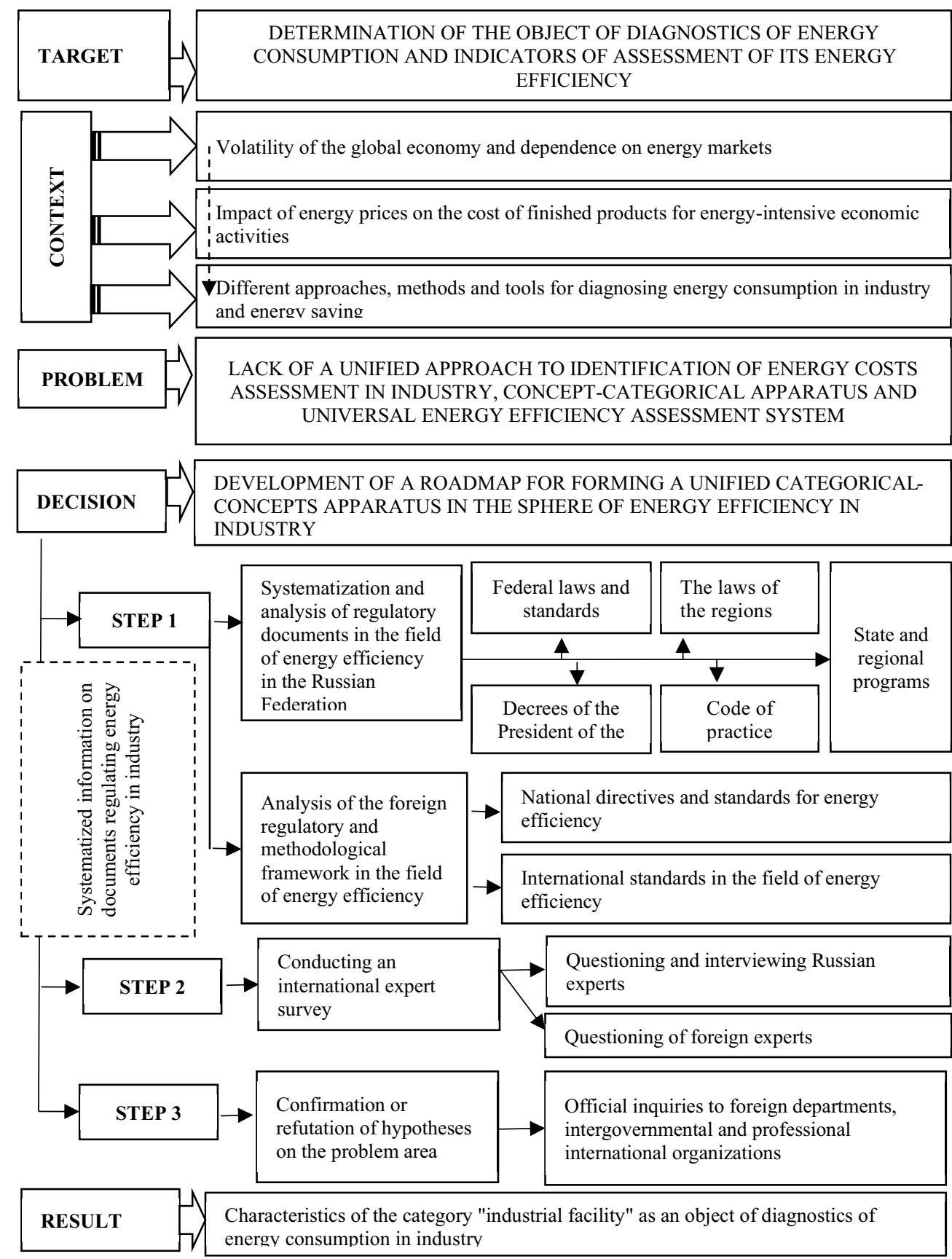

Fig. 1. Scheme of the study on the formation of a categorical apparatus in the field of energy efficiency in industry.

The application of the above methods within the framework of the stages presented in Figure 1 made it possible to obtain the scientific results necessary for the further implementation of a scientific project to develop a methodology for assessing energy efficiency classes of industrial facilities. 


\section{Results}

An analysis of open sources on the research topic showed that energy efficiency is diagnosed as objects in most countries. At the same time, in a number of countries, in contrast to the Russian Federation, there is a directive form of energy inspection not only for residential apartment buildings under construction. The results of the analysis of the international reports of the IEA and the UNECE were obtained, the results for the objects of identification of costs: the energy efficiency of new non-residential buildings is estimated by $87 \%$ of countries, new residential buildings - 93\% of countries, the corresponding residential buildings - $93 \%$ of countries, the corresponding non-residential buildings - $81 \%$ of countries, houses for single family - $88 \%$ of countries, apartment buildings - $94 \%$ of countries, commercial buildings $81 \%$ of countries, public buildings $-94 \%$ of countries [14]. This, in general, corresponds to a unified approach to defining a set of assessments for the level of energy efficiency of countries in the world. At the same time, in some countries there is their own, in greater detail, classification of objects by the level of energy efficiency, presented in the table. 1 [14].

Table 1. National building classifications for assessing the level of energy efficiency in European countries.

\begin{tabular}{|c|c|}
\hline The country & National Energy Classification of Buildings \\
\hline Albania & Evaluated: stone, brick and panel houses \\
\hline Bulgaria & $\begin{array}{l}\text { Evaluated: residential buildings (including hostels); buildings for civil service } \\
\text { (administrative service; education and science: schools, universities, } \\
\text { kindergartens and nurseries); medical institutions; buildings to serve the } \\
\text { population in the hotel industry; commercial buildings; buildings for sports; } \\
\text { buildings in the field of culture and art. }\end{array}$ \\
\hline $\begin{array}{l}\text { Bosnia and } \\
\text { Herzegovina }\end{array}$ & $\begin{array}{l}\text { Evaluated: residential, apartment buildings and individual houses; non- } \\
\text { residential administrative buildings (for education, social sphere and health care), } \\
\text { commercial building (for sports and recreation, tourism and public catering). }\end{array}$ \\
\hline Germany & $\begin{array}{l}\text { All buildings that require energy for heating or cooling (regardless of ownership, } \\
\text { size, etc.) are assessed, including new / appropriate and residential / non- } \\
\text { residential. Exceptions are temporary buildings, commercial buildings for } \\
\text { growing animals and plants, and religious buildings. }\end{array}$ \\
\hline Italy & $\begin{array}{l}\text { Buildings of } 8 \text { categories are assessed: residential; offices; hospitals and similar; } \\
\text { health-improving and associative with religious activities and similar; } \\
\text { commercial; sports buildings; educational; industrial and similar. }\end{array}$ \\
\hline Spain & All buildings are assessed. \\
\hline Portugal & Existing and new buildings are assessed: residential, public, commercial. \\
\hline Serbia & $\begin{array}{l}\text { Evaluated: residential single-family houses; residential buildings with two or } \\
\text { more apartments; administrative and commercial buildings; buildings of } \\
\text { education and culture; health and welfare buildings; tourist and hotel buildings; } \\
\text { buildings for sports and entertainment; buildings for trade and services; mixed- } \\
\text { use buildings; other buildings that use energy. }\end{array}$ \\
\hline Montenegro & $\begin{array}{l}\text { Evaluated: single-family homes; apartment buildings; commercial buildings } \\
\text { (hotels, recreational facilities, cultural facilities, warehouses, light industry } \\
\text { facilities); public buildings (schools, kindergartens, universities, hospitals, } \\
\text { dormitories); buildings heated at temperatures above } 12^{\circ} \mathrm{C} \text {, occupying an area } \\
\text { of more than } 50 \text { sq.m. }\end{array}$ \\
\hline
\end{tabular}

From the data in Table 1, it can be concluded that of the entire set of objects for assessing the level of energy efficiency, only Italy singles out industrial buildings in a separate class. However, within the framework of this study, it is of fundamental importance to determine the energy efficiency of an industrial facility, a category that is not identical to an industrial building. 
In the course of the study, the following terms were analyzed and selected for assessment from a large number of possible definitions in Russian regulatory legal acts (Table 2):

Table 2. Systematization of definitions of an industrial facility and related categories, defined in Russian regulations.

\begin{tabular}{|c|c|c|}
\hline Category & $\begin{array}{l}\text { Urce (regulatory } \\
\text { document) }\end{array}$ & Definition \\
\hline Industrial complex & $\begin{array}{c}\text { Law of the Moscow } \\
\text { dated October 7, 2015 N } 55 \\
{[15]}\end{array}$ & $\begin{array}{l}\text { These are real estate objects used in the field of } \\
\text { activity in the field of industry for the } \\
\text { implementation of activities in the field of industry } \\
\text { and engineering. }\end{array}$ \\
\hline Factory, plant & GOST R 58033-2017 [16] & $\begin{array}{l}\text { An industrial enterprise with a mechanized and } \\
\text { automated method of production, including one or } \\
\text { more interconnected buildings, in which production, } \\
\text { administrative and auxiliary premises are located, } \\
\text { according to the production technology of the } \\
\text { products. }\end{array}$ \\
\hline Industrial plant & $\begin{array}{l}\text { Set of rules } 18.13330 .2019 \\
{[17]}\end{array}$ & $\begin{array}{l}\text { A complex of buildings and structures of a } \\
\text { production facility located within the allotted land } \\
\text { plot, intended for the production of industrial } \\
\text { products. }\end{array}$ \\
\hline Industrial production & $\begin{array}{l}\text { Federal Law of December } \\
31,2014 \text { N 488-FZ [18] }\end{array}$ & $\begin{array}{l}\text { On the basis of the All-Russian Classifier of Economic } \\
\text { ActivitiesThe set of economic activities related to the } \\
\text { extraction of minerals, manufacturing, the provision of } \\
\text { electricity, gas and steam, air conditioning, water } \\
\text { supply, sewerage, waste collection and disposal, as } \\
\text { well as the elimination of pollution. }\end{array}$ \\
\hline $\begin{array}{l}\text { Enterprise, object of } \\
\text { economic }\end{array}$ & GOST R 58033-2017 [16] & $\begin{array}{l}\text { The whole complex of territorially close } \\
\text { organizational and (or) technologically interconnected } \\
\text { objects under the control of an economic entity } \\
\text { responsible for the acquisition, development, } \\
\text { production, supply of products, provision of services, } \\
\text { performance of work in accordance with the contract. }\end{array}$ \\
\hline $\begin{array}{l}\text { Object designated for } \\
\text { production }\end{array}$ & $\begin{array}{c}\text { Set of rules } \\
132.13330 .2011[19]\end{array}$ & $\begin{array}{l}\text { Buildings used for production and assembly work, } \\
\text { warehouse buildings. }\end{array}$ \\
\hline Production facility & $\begin{array}{l}\text { Set of rules } 18.13330 .2019 \\
{[[20]}\end{array}$ & $\begin{array}{l}\text { Enterprises of various industries of industrial and } \\
\text { agricultural purposes, including warehouses, } \\
\text { engineering and transport infrastructure, } \\
\text { communication facilities, utility facilities. }\end{array}$ \\
\hline \multirow{3}{*}{ Industrial facility } & $\begin{array}{l}\text { GOST R 56828.15-2016 } \\
{[21]}\end{array}$ & $\begin{array}{l}\text { Stationary technological unit, where one or more types } \\
\text { of activities are carried out, listed in the List of } \\
\text { application areas of the best available technologies } \\
\text { (BAT), approved by the order of the Government of } \\
\text { the Russian Federation of December 24, 2014 N 2674- } \\
\text { r. }\end{array}$ \\
\hline & $\begin{array}{l}\text { Decree of the President of } \\
\text { the Russian Federation } \\
\text { 06.05.2018г. № } 198 \text { [22] }\end{array}$ & $\begin{array}{l}\text { The enterprise, its workshops, sites, sites used for the } \\
\text { implementation of activities in the field of industry. }\end{array}$ \\
\hline & GOST R 57306-2016 [23] & $\begin{array}{l}\text { Stationary equipment and / or structures used in } \\
\text { connection with any technological process or system } \\
\text { for industrial production or product release, or as part } \\
\text { of them }\end{array}$ \\
\hline
\end{tabular}

In the course of the analysis of Russian regulatory documents, it was revealed that the category "industrial facility" is mentioned in several documents:

- in GOST R 56828.15-2016 "Best available technologies. Terms and Definitions";

- in the Decree of the President of the Russian Federation dated 06.05.2018. № 198 "On the foundations of the state policy of the Russian Federation in the field of industrial safety for the period up to 2025 and beyond";

- in GOST R 57306-2016 "Engineering. Terminology and basic concepts in the field of engineering ". 
Thus, we can say that the category "industrial facility" has a special focus depending on the intended purpose of each of the above-presented regulatory documents.

This is the primary research problem, which has caused the need to clarify the basic category of research "industrial facility".

An expert survey was conducted to formulate a universal category "industrial facility". In view of the unity of the problem area of research at the international level, it was decided to conduct an international survey of leading experts on the topic of the ongoing scientific project.

The experts were asked to choose one of the proposed options or enter their own answer:

- an industrial building or a complex of adjacent buildings, including its entire property complex, with a single engineering infrastructure that ensures the production activity of an economic entity;

- an industrial building used for the production of raw materials / semi-finished products / finished products;

- enterprise, workshop, site, unit and other production units

- a building with standard space-planning and structural solutions, in accordance with the type of economic activity;

- a stationary technological unit, where one or more types of production activities are carried out, carried out at one industrial site and which may have a negative impact on the formation of emissions, discharges, waste and other pollution.

Based on the analysis of the results obtained, it was revealed that for the purpose of assessing the level of energy efficiency of an industrial facility, it is necessary to consider: an industrial building or a complex of adjacent buildings, including its entire property complex, having a single engineering infrastructure that ensures the production activity of an economic entity. The survey involved experts from the Russian Federation, Uzbekistan, Lithuania, Sweden, Italy, Germany, Austria, Sri Lanka.

Based on the above interpretations of the category "industrial facility" (Table 2), taking into account expert opinion, theoretical knowledge in the subject area of research and the experience of practical activities of members of the research team in the field of energy audit, the following definitions are proposed on the topic of research:

An industrial enterprise is a property complex intended for carrying out entrepreneurial activities in the field of industry.

An industrial enterprise can include one or more industrial facilities.

An industrial facility is a set of industrial buildings, structures, structures, geographically isolated and organizationally and technologically interconnected, equipped with energyconsuming equipment and ensuring the continuity of the technological cycle of industrial production.

Clarification of the category "industrial facility" will contribute to the further formation of a categorical-conceptual apparatus in the field of energy efficiency in industry and the development of methodological solutions for assessing the energy consumption of industrial facilities.

\section{Discussion}

In modern conditions, the issue of increasing energy efficiency in industry is quite relevant in the world. The key role in its solution belongs to the United Nations Economic Commission for Europe (UNECE). The UNECE region includes 56 member states, including Western European (European Union and non-European Union), North America (Canada and the United States), South-Eastern Europe, Eastern Europe, Caucasus, Central Asia, Israel, Turkey and the Russian Federation. 
The initiative «The Sustainable Energy for All» has set a goal of doubling the global rate of improvement in energy efficiency by 2030 , increasing energy efficiency by $2.6 \%$ per year, and meeting the goals of the Paris Climate Agreement [24]. However, the current problem is that the rate of improvement in energy efficiency is lower than planned. At the same time, the industrial sector accounts for about a third of the world's final energy consumption and $\mathrm{CO} 2$ emissions. According to experts' forecasts, economic measures to improve energy efficiency, based on existing technical solutions, can reduce energy consumption in the industrial sector by $30 \%$. When using promising technological innovations, energy consumption can be reduced by up to $60 \%$ [25].

To this end, a Task Force on Energy Efficiency in Industry was established, established by the Committee on Sustainable Energy in September 2018, with a mandate for 2019-2020 extended further to 2022. The primary task for the Task Force was identified: to clearly articulate what is understood under "energy efficiency in industry", define its role in sustainable energy, identify "non-energy" benefits for enterprises.

Thus, at present, in the world space, there is no understanding of the category that characterizes the object of diagnostics of energy consumption in industry. This aspect confirmed the relevance of this issue not only for the Russian Federation, but also for other countries of the world.

Foreign specialists of the Technical University in Vienna, Austria, proposed a scheme and methods of integrated design, and systems for modeling and calculating the expected effect, taking into account the technological and production specifics [26]. The developed modeling and evaluation system takes into account three groups of fundamental input data: building, energy and production process. Within the framework of the study, it is proposed to form a methodology for assessing an industrial facility based on two of the groups presented: for a building, as a real estate object with characteristic space-planning and structural solutions, as well as a technological process characterized by the equipment used for the corresponding type of economic activity.

\section{Conclusion}

The analysis of open sources on the research topic showed that a separate building is considered as objects of energy consumption assessment in most countries of the world community.

In the course of the analysis and systematization of the set of definitions of an industrial facility and related concepts reflected in various regulatory documents of the Russian Federation, it was revealed that the category "industrial facility" has a special focus depending on the intended purpose of the document in which it is mentioned. This circumstance required a separate consideration of the category "industrial facility" in the framework of an expert survey with the involvement of Russian and foreign experts in the field of energy efficiency.

Based on the analysis of the obtained results of the expert survey, the basic category of the study "industrial object" was clarified, which should be understood as: an industrial building or a complex of adjacent buildings, including its entire property complex, which have a single engineering infrastructure that ensures the production activity of an economic entity.

The practical significance of the results obtained is that the refined basic category "industrial facility" includes a building and engineering infrastructure associated with the technology of production for a specific type of economic activity. This is the basis for further research and development of energy efficiency indicators, which are the basis for benchmarking the energy efficiency of industrial enterprises.

The reported study was funded by RFBR, project number 20-010-00754. 


\section{References}

1. I. A. Bashmakov, Industria Salutaris, 1 (2021)

2. I. A. Bashmakov, Industria Salutaris, 6 (2020)

3. Yu. A. Tabunshchikov, Industria Salutaris, 1 (2019)

4. Yu. A. Tabunshchikov, Industria Salutaris, 6 (2018)

5. N. V. Shilkin, AVOK, 5 (2017)

6. N. V. Shilkin, AVOK, 7 (2017)

7. Mokhtara, M. Nasootib, Energy Strategy Reviews, 28, 100458, March (2020)

8. D. Borozan, D. P. Starcevic, Renewable and Sustainable Energy Reviews, 116, 109401, (2019)

9. B. Ezicia, G. Eğilmezb, R. Gedikc, Journal of Cleaner Production, 253, 119630 (2020)

10. O. T. Adenuga, K. Mpofu, B. I. Ramatsetse, Procedia Manufacturing, 51, pp. 243-250 (2020)

11. Y Hanab, R. Zhouab, Z. Gengab, J. Baiab, B. Mac, J. Fand, Journal of Cleaner Production, 246, 118965 (2020)

12. J. Palma, P. Thollanderbc, Reframing energy efficiency in industry: A discussion of definitions, rationales, and management practices, Energy and Behaviour, Towards a Low Carbon Future pp. 153-175 (2020)

13. A. Gonzalez Hernandeza, S. Cooper-Searleb, Alexandra C.H. Skeltona, Jonathan M. Cullena, Energy Policy, 120, pp. 533-549 (2018)

14. Comparative review of aedificium navitas efficientiam et signa vitae in Nationum Commissio Oeconomica pro Europa regione. Geneva (2018)

15. Legem de Civitate Moscua octobris, 7, N 55 " In Industriae Consilium de Civitate Moscua» (2015)

16. GOST R 58033-2017 Nationalibus Vexillum of Russian Foederatio "Aedificia". Lexicon. Pars 1. Generalibus (2017)

17. SP 18.13330.2019 Productio facultatem. Consilio ordinationem terra insidiarum (2019)

18. Foederati Lex, N. 488-FZ December 31, 2014 " In Industriae Consilium in Russian Foederatio »

19. SP 132.13330.2011 Cupimus, anti-terroristis praesidio aedificia. Generale consilium requisite (2011)

20. SP 18.13330.2019 Productio facultatem. Consilio ordinationem terra insidiarum (2019)

21. GOST R 57306-2016 Ipsum. Terminis et basic conceptus in agro ipsum (2016)

22. Decretum de Praeses Russian Foederatio No. 198 de 06.05.2018 "In Fundamenta rei Publicae Consilium in Russian Foederatio in agro Cursus Salutem pro temporis usque ad 2025 et Ultra» (2018)

23. GOST r 56828.15-2016 Nationalibus Vexillum of Russian Foederatio Optimum available vitae. Terminos et definitions (2016)

24. Draft Actio Consilium melius Efficientia Industria in Industria et taxationem munus Nationum Commissio Oeconomica pro Europa in eius exsequendam (2020)

25. Superatis claustra ad navitas efficientiam elit. Nationum. Novum Eboracum et ad Genavam (2017) 